InOedia $\quad \begin{aligned} & \text { InMedia } \\ & \text { The French Journal of Media Studies }\end{aligned}$

5 | 2014

Media and Diversity

\title{
"Walking Up a Down-Escalator": The Interplay Between Newsroom Norms and Media Coverage of Minority Groups
}

Brad Clark

\section{(2) OpenEdition \\ Journals}

Electronic version

URL: http://journals.openedition.org/inmedia/749

DOI: $10.4000 /$ inmedia.749

ISSN: 2259-4728

Publisher

Center for Research on the English-Speaking World (CREW)

\section{Electronic reference}

Brad Clark, " "Walking Up a Down-Escalator": The Interplay Between Newsroom Norms and Media Coverage of Minority Groups », InMedia [Online], 5 | 2014, Online since 17 October 2014, connection on 08 September 2020. URL : http://journals.openedition.org/inmedia/749 ; DOI : https://doi.org/ 10.4000/inmedia.749

This text was automatically generated on 8 September 2020.

(c) InMedia 


\title{
"Walking Up a Down-Escalator": The Interplay Between Newsroom Norms and Media Coverage of Minority Groups
}

\author{
Brad Clark
}

1 Canadian scholars have consistently found mainstream news coverage of Aboriginal peoples and visible minorities to be negative, stereotypic and non-inclusive. ${ }^{1}$ However, Canadian research on media representations of minorities has focused more on newspaper coverage than television, despite legislation calling on broadcasters to reflect the country's "multicultural and multiracial nature" on the air waves. ${ }^{2}$ The federal broadcast regulator, the Canadian Radio-television and Telecommunications Commission (CRTC) requires broadcasters to file annual diversity reports and states that "upholding cultural diversity is one of the key goals" of the Broadcasting Act. Yet the studies that have examined the Canadian television news discourse have arrived at the same concerns over under- and misrepresentation. ${ }^{3}$ Solutions to improve news coverage of minority groups - across all media lines - have often focused on diversity awareness and education in news organizations, as well as human resources solutions, that is, hiring more people from diverse ethnic backgrounds. ${ }^{4}$ In Canada, this has also become a matter of regulatory policy for broadcasters, who must follow provisions of the Employment Equity Act (1988) to enhance opportunities for four "marginalized" groups: women, visible minorities, Aboriginal peoples and people with disabilities. ${ }^{5}$ Despite these measures, research shows Aboriginal peoples and visible minorities are still under-represented as both on-air personnel and sources. ${ }^{6}$ In fact, and perhaps symptomatic of that under-representation, some scholars argue that the mainstream media continue to "transmit powerful and negative images about ethno-cultural groups". The implications of consistently inequitable news coverage are summed up well by Mahtani, who writes: 
Ethnic minorities in Canada do not see themselves mirrored in the media, and this perpetuates feelings of rejection, trivializes their contributions, and devalues their role as citizens in their nation. ${ }^{8}$

2 With respect to Aboriginal peoples, inaccurate and incomplete news media portrayals have led to a "disconnection" between the public opinion of perceived government "handouts", and the reality of much higher rates of poverty in indigenous communities compared to non-Aboriginal Canadians, a misperception which may well stand in the way of '“costly' initiatives designed to improve the lives and autonomy of Aboriginal people". 9

3 Much of the research related to news media representations of minority groups takes the form of content analysis ${ }^{10}$ or case study.$^{11}$ However, this inquiry targets one of the key environments where the mainstream media discourse is produced: the newsroom. Cottle makes the case for the "in-depth understanding" newsroom studies provide, and specifically identifies a need for such research "in respect of gender and minority ethnicity", as it relates to "news production and practices". ${ }^{12}$ This study examines production norms and long-held news values, as well as newer measures aimed at improving inclusivity and the nature of minority news coverage. The study incorporates participant observation data, interviews with members of the current affairs and newsgathering staff and management, and documents from a Canadian Broadcasting Corporation ( $\mathrm{CBC}$ ) radio and television operation in Western Canada. The analysis suggests well-established production norms often stand in the way of more inclusive, less negative and stereotypic coverage of non-white ethnic groups. Moreover, normative pressures to cover "hard news" often derail approaches to newsgathering aimed at mitigating mainstream, Eurocentric bias. The drive for reform, as exemplified by this study, has been described by one scholar as "walking up a down-escalator". ${ }^{13}$

\section{Literature Review}

4 Scholars throughout the Western world have consistently found media representations of ethno-cultural minorities to be problematic. Van Dijk argues that minority groups "are seen as a problem or a threat, and are portrayed in association with crime, violence, conflict, unacceptable cultural differences, or other forms of deviance". ${ }^{14} \mathrm{~A}$ comparative analysis of media policies in Europe and the United States highlights the tensions between dominant and minority groups, but concludes that "the aim to integrate different voices of the society into the media system" has not been reached in either region. ${ }^{15}$

5 The experience in Canada is similar. Fleras captures the prevailing view, arguing that mainstream news "perpetuates the framing of minority women and men as troublesome constituents - little more than problem people who are problems, who have problems, and who create problems involving cost or inconvenience". ${ }^{16}$ Jiwani points to a body of research showing that media portrayals of "racialized minorities tend to cluster around the themes of crime and deviance, ethnic exotica, athletic prowess, and societal achievement, thereby constructing them as "Others" - different from 'us", which in turn evokes "negative connotations linking immigrants with fears of invasion, illegal entry, and opportunistic behavior". ${ }^{17}$ Henry and Tator's critical discourse analyses of Canadian newspapers reveal a form of "democratic racism", despite the perception of a "tolerant" Canadian society. ${ }^{18}$ Other researchers have also 
documented misrepresentations in Canadian news media with regard to Muslim and Asian groups respectively. ${ }^{19}$ Studies examining newspaper coverage of Aboriginal peoples in Canada have identified persistent colonial stereotypes, ${ }^{20}$ reflected in stories that generally focus on "a pathological reliance on welfare, a predilection for alcohol and substance abuse, an inclination to laziness and lack of ambition, and a temptation to mismanage what little they have". ${ }^{21}$ Canadian researchers have illustrated both the depth of under-representation and the lack of context in news stories related to indigenous peoples. ${ }^{22}$

Efforts to improve news coverage of minority groups have long been tied to bringing diversity to the ranks of news staff, a view most explicitly highlighted for the first time in North America by the Kerner Commission in the United States, which was established to address issues of race and civil rights in the wake of rioting and unrest in the late 1960s. The commission suggested media were blind to the racial issues that ignited the troubles, such as poverty, discrimination and chronic unemployment, noting that news coverage of black communities was inaccurate, sensational and onesided. ${ }^{23}$ Key recommendations by the commission included calls for more inclusive reporting, the hiring of black reporters, and the promotion of "Black journalists into decision-making jobs". ${ }^{24}$ This view of newsroom diversity has been advocated by both journalistic organizations ${ }^{25}$ and scholars ${ }^{26}$ around the world.

7 In Canada, the news staff diversity approach was strongly supported by a task force commissioned by the CRTC to improve television representations of ethno-cultural groups. The task force's final report recommended the adoption of "best practices", including newsroom awareness of diversity, but also the hiring of editorial staff from marginalized groups. ${ }^{27}$ Another broadcast industry group, the Radio-Television News Directors Association (RTNDA Canada) advocates a similar package of recommendations based on recruiting minority journalists, education and awareness..$^{28}$ While these initiatives are voluntary, the CRTC requires broadcasters to file diversity reports on their activities related to "reflecting" minority communities in Canada. Murray contends that these reports tend to focus on broad measures rather than on specific steps to improve news coverage, describing the overall tone of these reports as "policy positivism", with a focus repetition on counting and boosting equity numbers, while avoiding issues related to the way minorities are portrayed and "broader questions of narrative and discourse". ${ }^{29}$ Despite these measures, Miller points out, "there has been little done to investigate any direct correlation between the representation of ethnic minorities in newsrooms and the resulting coverage". ${ }^{30}$

The fundamental assumption in the hiring approach is that minority reporters will bring their experiences, viewpoints and contacts in their communities to bear on the news content; however, it might not be so simple. Hall contends hegemony shapes the way media messages are formed and received, theorizing that media elites "encode" messages from "within the wider socio-cultural and political structure of which they are a differentiated part". ${ }^{11}$ Television journalists package the "dominant definitions" in a professional manner that is said to be "relatively independent", but the story ultimately carries "the stamp of legitimacy" appearing "'natural', 'inevitable', 'taken for granted". ${ }^{32}$ Shoemaker and Reese draw the connection between hegemony, objectivity and the reliance on official sources in the journalistic routine. They argue journalists have come to be regarded as "biased when they use their own expertise to draw conclusions", but "objective when they let prominent sources dictate the news". ${ }^{3}$ 
The result is an over-representation of official "bureaucratic" sources. ${ }^{34}$ To be considered a legitimate source, a person needs to be in a position of authority, and seen as a "knower". ${ }^{35}$ As Ericson, Baranek and Chan (1989) conclude, "news represents who are the authorized knowers and what are their authoritative versions of reality" ${ }^{36}$ In a racial context, scholars have also noted that minority voices are in short supply "where reporters habitually go for expertise". ${ }^{37}$

The limited research in this area - all from outside Canada - suggests journalistic norms and professional ideals do impede minority journalists. Interviews with black and Latino newspaper reporters in the United States reveal journalistic norms such as objectivity and neutrality "constrain" the journalist's ability to "enhance the news reports on minorities", but that there is an opportunity for "stealth advocacy" and to foster an environment of enhanced sensitivity to ethno-cultural issues. ${ }^{38}$ Pease, Smith and Subervi also find a link between a newsroom culture of support for diversity and "the quality of the news product". ${ }^{39}$ On the other hand, Wilson, noting low and stagnant participation rates among US minority reporters, concludes:

Placing Black journalists in the almost total racial and cultural isolation of the newsroom where operative news values, procedures and policy have long been ingrained to exclude the African American perspective obviates their effectiveness as agents for change. ${ }^{40}$

10 In the United Kingdom, Cottle's study of the British Broadcasting Corporation (BBC) also highlights challenges for minority journalists in a mainstream media environment. He suggests minority television producers are constrained by the "corporate context" and the "professionalism" that imbues the $\mathrm{BBC}$, to the point where they "are wary of becoming too closely involved with a particular community and its representatives since this could be interpreted as compromising their claim to professionalism". ${ }^{41}$

11 These studies challenge the assumption that a more diverse newsroom in and of itself will result in more equitable, inclusive news coverage of ethno-cultural groups. There appears to be a link, but clearly other influences are at play. In the Canadian context of broadcast newsroom diversity there has been no analysis of the production environment to determine these variables, despite the implications for federal legislation and regulatory policy. Indeed, Mahtani underscores this critical gap in the research, advising "we would do well to pay greater attention to the sites where news is produced, like the newsroom". ${ }^{42}$ Downing and Husband have similarly noted a "paucity" of studies examining media production in the context of race. ${ }^{43}$ This study aims to fill that void, examining the newsroom influences that both enable and inhibit more inclusive, equitable news content. To explore these issues I arranged to study a newsroom of the $\mathrm{CBC}$, Canada's national public broadcaster, incorporating ethnographic methods of participant observation, interviews and document collection.

\section{Methodology}

Newsroom observation as a form of ethnographic research dates back more than six decades to David Manning White and his famous case study of how "one of the gate keepers" in the world of communications "operates his gate". ${ }^{44}$ Other iconic studies have also relied on ethnographic approaches, focusing on news production and the newsroom, substantially increasing the understanding of journalistic practice. ${ }^{45}$ 
Ethnography, as a method of inquiry in the field of journalism, is considered well suited to probing issues of race in media discourse in order to "better understand the forces that contribute to the under-representation of ethnic minorities within the media workforce as well as their misrepresentation in terms of media portrayal". ${ }^{46}$

Critics of ethnography highlight issues of validity, reliability and transparency, contending that researchers "can only offer interpretations of what they see and hear". ${ }^{47}$ Indeed, much scholarly debate has been dedicated to figuring out how to ensure "participant voices" are not "too strongly filtered" by the researcher. ${ }^{48}$ To mitigate researcher subjectivity ethnographers often turn to grounded theory, where "the theory that emerges from the study is derived from and 'grounded' in data that have been collected in the field, rather than taken from the research literature". ${ }^{49}$ Grounded theory does not set out to arrive at specific findings or "a few themes"; it is "an integrated theoretical formulation that gives understanding about how persons or organizations or communities experience and respond to events together". ${ }^{50} \mathrm{Charmaz}$ distinguishes the constructivist approach to grounded theory, used in this study, by pointing out that the method "lies firmly in the interpretive tradition ... it not only theorizes the interpretive work that research participants do, but also acknowledges the resulting theory is an interpretation". ${ }^{51}$ The priority, she writes, is "to the studied phenomenon or process - rather than to a description of the setting", ${ }^{52}$ providing an appropriate design for this analysis, given the complex forces shaping news content in the production environment.

I approached a $\mathrm{CBC}$ operation in Western Canada as a potential site for this study. As a former $\mathrm{CBC}$ journalist, I hoped my ties to the organization would help negotiate access, and that my familiarity with the corporate culture, newsroom software, and communication systems would facilitate the research. As a public broadcaster, CBC's mandate extends "the reflection of multicultural and multiracial" Canada to all regions across the country; ${ }^{53}$ it broadcasts in both French and English from coast to coast and provides service in indigenous languages in the far North. In recent years, $\mathrm{CBC}$ has also offered its flagship Hockey Night in Canada sportscast in languages such as Mandarin, Cantonese and Hindi. The success of its Punjabi broadcasts has resulted in weekly livestreaming and cable broadcasts of National Hockey League games. ${ }^{54}$ Diversity in CBC's news content, as documented by a recent study, shows that minority participation rates for both on-air personnel and news sources are slightly higher compared to the private-network news. ${ }^{55}$ However, at the time of writing, $\mathrm{CBC}$ is in the midst of an organization-wide "corporate plan" to boost diversity among its staff, particularly for Aboriginal peoples, visible minorities and people with disabilities. ${ }^{56}$

Locally, this CBC station in Western Canada had monitored its own programming for inclusivity, worked with consultants to build more diverse content, deployed crosscultural funding to create content on First Nations, and organized community-outreach campaigns aimed at Aboriginal and immigrant communities. Without revealing too much about the location, there is a higher than average Aboriginal population inside city limits and in the surrounding communities, and fairly diverse immigrant groups, all of which is typical of urban centers in this part of the country.

16 After many weeks of discussions, the $\mathrm{CBC}$ and I came to an agreement. Aside from the details already disclosed, I agreed with CBC's request not to reveal the location of the study or the identities of any of the people employed there. To assure anonymity, interviewees quoted in this paper are identified by number (e.g. interview 1, interview 
2, etc.). I also promised to share my findings with the organization. I was given free rein to attend story meetings, take notes, and wander around the newsroom. Once on site, I was set up with a computer account giving me access to news wires, national and local news outlooks, scripts and some of the organizational communications.

I began "hanging out" in July, 2012. The daily routine of the newsroom closely followed the schedule I had participated in at other CBC locations. I attended the main story meeting for most journalists first thing in the morning as well as the producers/ assignment meeting that immediately followed. In these meetings I was able to observe key exchanges related to story selection, assigning and sourcing. Outside these meetings my time was spent monitoring programming, chatting informally with staff, or conducting recorded interviews in an office just off the newsroom. I collected 58 pages of local and national news agendas, about 20 pages of observational notes and analytic memos based on story meetings, informal chats with newsroom staff and monitoring of the news content. In total I spent close to 100 hours on site.

Sixteen formal, recorded interviews provided the largest data set. They were often conducted at the end of the journalist's shift. Two additional interviewees requested not to be recorded, but sat down with me and consented to note-taking. Management estimated the total editorial staff at about 45. I aimed for a cross-section of participants across newsrooms roles, gender and ethnicity. A third of the interviewees came from a minority background and the split among women and men was exactly even. I went into each interview with a guide of nondirective questions to allow interviewees to describe the routines, rituals and influences on their work. In the actual process of conducting interviews, some directive questions were also included to contrast the interviewee's experiences against those of other participants.

The study is not without its limitations. Broadcast news operations are complex organizations and it is neither practical nor possible to observe all the decision-making processes and interactions that might shape news content. The findings that emerge from the data are a reflection of the participants who agreed to be interviewed. The study period was relatively short, but given my familiarity with the $\mathrm{CBC}$, I was able to get to a point of "saturation", where "no new concepts ... emerge" ${ }^{57}$ In other words, by the end of my fieldwork, patterns in the news production process were repeating and interview subjects were raising the same points. Despite some of the challenges, I was able to collect extensive, rich data on the newsroom forces shaping media representations of minority groups.

The data analysis process of the transcribed interviews and field notes began with the open-coding referred to by Strauss and Corbin as "microanalysis", ${ }^{58}$ followed by Charmaz's "focused coding" synthesizing the most "significant" or frequent codes. ${ }^{59} \mathrm{I}$ initially arrived at 11 categories and roughly 50 subcategories, including some in vivo codes such as "doing more with less", and "feeding the goat". However, after further analysis I was able to distill the original 11 codes into four major categories, outlined in the next section.

\section{Findings}

21 This study set out to uncover what newsroom influences either boost or inhibit "better" representations of minorities in media content. The data show that "better" coverage is enhanced by: a supportive corporate culture (managers make diversity a 
priority); ample resources (more reporters being given more time); and greater staff diversity (hiring editorial staff from different cultural and religious backgrounds). Factors that inhibit equitable, inclusive content are the established newsgathering routines (norms and news values), and their connection to an unspoken mainstream (white) bias. What follows is an examination of those four major categories and their related subcategories.

\section{Corporate Culture}

In interviews and informal chats virtually everyone at $\mathrm{CBC}$ consistently underscored diversity as an important and explicit organizational goal. One member of the management team noted that it is the public broadcaster's mandate to provide strong journalism "that resonates with individual Canadians" and "enhances democracy", arguing that "you can't have an engaged audience if you're not reflecting the various demographics". ${ }^{60}$ On a more practical level, this manager cited the "business case" for building audience through diversity: "If people see themselves reflected, they'll consume your product." One reporter felt "that conscious push" of the station's diversity agenda motivates her to find sources that "reflect this town ... don't just go to, you know, a white person". ${ }^{61}$ However, staff at all levels suggested the content had not been very inclusive. Before my arrival, a staff member monitored television news for a period of time to see how and how often visible minorities, women, Aboriginal peoples, and people with disabilities were represented..$^{62}$ According to this manager, the findings from this analysis were telling:

I mean, it was the worst possible result. So it showed that Aboriginal people were almost always portrayed as perpetrators or victims of crime or as down-and-outers in general. Authority figures were always white men. It was - it was a very, very damning document. ${ }^{63}$

Other staff members cited similar data from separate, ongoing analysis by Frank $\mathrm{N}$. Magid Associates, a well-known US-based consultant that has worked with most major North American networks. ${ }^{64}$ Part of the consultant's focus with this station has been an attempt to build audience through more inclusive news. One journalist stated that according to the Magid analysis "we're not doing very well in terms of our representation". ${ }^{65}$ Nonetheless, when asked how to address the issue, participants routinely indicated a supportive corporate culture was essential, "a starting point". This recognition was often accompanied by persistent calls for "more": more resources, more original news and more journalists and managers from minority backgrounds.

\section{Staff Diversity}

Management at the station listed hiring as an important component of its diversity strategy, and there is some representation of visible minorities and Aboriginal people among the hosts/anchors. This is also true of the pool of journalists, although virtually everyone interviewed for this study described the management and assignment team the same way: "very white" and "not very diverse at all". In interviews and informal conversations around the newsroom there was widespread support for greater participation from marginalized groups at two levels: (a) among the editorial staff of reporters, producers, hosts and anchors (content providers), and (b) in the ranks of managers and senior producers/assignment editors (decision-makers). 


\section{(a) Diversity among Reporters/Producers}

from their own communities that they had initiated. During my time in the field, a Muslim reporter put together a feature on a Muslim professional athlete observing the traditional fast during Ramadan, despite the rigors of training and competition. The reporter said the idea started with a simple observation that a big segment of the population (the Muslim community) was going around hungry all day, while the rest of the city was completely unaware. About a week later another Muslim journalist suggested a slightly different take on Ramadan, a campaign to sell "Ramadan dates" as a way to raise money for Syrian refugees. Dates are a staple in the Middle East and a popular treat when the daily fast ends at sunset. That story did not make it to air. In another case an Aboriginal journalist had advocated coverage and feature interviews with a regional candidate in the race for the leadership of the Assembly of First Nations, a national body representing Aboriginal peoples from across Canada. The interview was never booked despite many attempts, but the story was covered over several programs and platforms.

Some journalists, however, acknowledged getting such stories from their own communities to air often requires an extra "push":

Recently we had this good story. It was refugees ... doing those homeless dinners, like, feeding the homeless people ... And I knew it was an awesome story. I knew everybody involved were really good talkers and everything ... But it just falls through the cracks in the middle of everything. And then we just, one day, we just had no stories for someone and then [someone was assigned to do it] and then it was, for three days we were doing the story. ${ }^{66}$

Another staffer had an example of a story about a nearby Aboriginal community that also "fell through the cracks" and did not make it to air. It involved elementary schoolchildren planting vegetable gardens in containers known as "Earth boxes" as part of a study and initiative with a university. The crops grown went to an elder's home and to the school's lunch program. Despite some interest from at least one show producer, no one was assigned due to concerns about travel time and limited staffing. However, when an international conference featured the program, people in the newsroom were asking why they had not done the story previously, a situation far too common for this producer: "So that's the frustration level. And so there's all kinds of stories like that all over the place that we just never do." 67

The Aboriginal and visible minority journalists interviewed see the value of an inclusive newsroom and their role in fostering more inclusive news, but they also recognized the unique challenges they face. They generally believed "it's OK to be the go-to-person" for specific ethnic communities, but one admitted it can "put you in a hard position sometimes ... your judgement is always in question" because of your ethnic background. Some non-white journalists suggested they play an important role in challenging stereotypic and negative coverage of their communities. Another minority journalist noted that her ability to speak the language and understand cultural sensitivities gives her an advantage over white reporters in building trust and gaining access to some communities. However, there is also recognition that minority reporters might not always be the clear conduit to more diverse news content. As one journalist pointed out, "just because you look like you're of a certain community ... I'm 
still middle class and college-educated and not necessarily connected with some of those stories". ${ }^{68}$

\section{(b) (Lack of) Management and Assignment-Desk Diversity}

Interviewees consistently pointed out key decision-makers in management/assignment are almost all white, educated and middle-aged, bringing a decidedly mainstream perspective to editorial choices: "I can't think of anybody [there] who taps into a visible minority constituency". ${ }^{69}$ After one big breaking news story cast a marginalized group in what was perceived to be a negative light, a frustrated producer blamed "the background of the people calling the shots". Other journalists raised similar concerns about the filter of decision-makers. One noted that what gets assigned depends on who is assigning "and their personal tastes". Another suggested one of the key criteria for story selection is "what are people talking about", a question too often answered through a narrow cultural lens:

Our perceptions are a product of where and how we live ... and who we hang out with, likely the like-minded. So 'what are people talking about' means what are people exactly like you talking about. ${ }^{70}$

The power of assignment editors to push ideas they were "talking about" to air was evident in several cases, most notably the story of parents deciding to teach their children multiplication tables on their own, because schools in the region had taken a different strategy. The idea was passionately pitched by a member of the assignment crew, a parent of school-aged children, and the story aired the next day. Reporters offered examples of their own from outside the study period, including stories about burglar alarms, air travellers getting bumped off flights, and explaining the Internet to children, stories that appeal to people from a certain socioeconomic status, people like those who staff the assignment desk.

\section{Resources}

31 Reporters and producers stated over and over that the station was "doing more with less". Even while I was there, staff held goodbye ceremonies for colleagues who had lost their jobs in the latest round of budget cuts to the public broadcaster. A majority of interviewees felt the tightening of resources - less staffing, more demands, less time eroded the station's ability to be more inclusive with news and current affairs content. They argued that more diverse content (a) requires additional effort and time, and (b) that it suffers when resources are not dedicated to community outreach.

\section{(a) Diversity as Additional Effort}

32 A number of interviewees view diversity in content as something that happens when there is sufficient time or staffing levels (this perception also comes up in the context of the news agenda and hard versus soft news, discussed in detail below). A reporter captured this point of view this way: "Generally it's harder to find someone who is not white to give you that information and if you're on a deadline you don't have time to look for somebody". ${ }^{71}$ Increasingly, according to this journalist, "ever increasing demands" leave virtually no time to develop sources within minority communities, 
"leading us down a path of least resistance ... [to] the people we've been talking to, people we know talk about this well".

On the other hand, there was also recognition that resources can be targeted to deliver the kind of content that management seeks. This interviewee pointed out a commitment to investigative journalism has fostered a continuous string of original and important stories: "We threw resources at excellence and we got some, and so you have to throw resources at diversity and you'll get some" ${ }^{72}$ However, not everyone interviewed cited resources as such an important factor in better representing minority groups. One journalist stated she simply has not experienced the effects of diminished resources on her reporting. Another participant argued it comes down to an ethical consideration, the desire to reflect the community and accurately represent all people, and provided the example of trying to find a real estate agent to interview for a story:

Chances are they're going to be diverse anyhow ... But if you're looking for one you have to have that consciousness. And [some reporters] think "it's something else I have to think about" ... I don't get it. I'm actually very puzzled by that. ${ }^{73}$

\section{(b) Community Outreach}

There was often recognition that in order for journalists to build trust in some ethnocultural communities, there had to be pre-emptive efforts to build relationships. One reporter observed that immigrants experience a lot of intolerance in the city. Moreover, newcomers often see their people represented in negative ways in the media, adding to the sense of apprehension in dealing with news organizations. Journalists highlighted some of the successes related to outreach efforts, such as a series of stories on a specific group of African immigrants as well as Asian and nearby Aboriginal communities.

Yet according to some journalists these efforts were increasingly the exception. One reporter explained some of the challenges she faces:

There's a Hindu community I've been connecting with, just on the phone ... I have no time to sit down with the head of the association and gain her trust and start asking about what's really going on in the community. ${ }^{74}$

Another reporter spoke of building ties with elders in an Aboriginal community, only to have that work undermined by a particularly negative feature by a network correspondent from outside the region. Nonetheless, journalists saw community outreach as important to developing sources outside the mainstream, sources who will let them know when there are stories or issues that are newsworthy, and who are willing to be interviewed by the media. When staff do not get that time, they suggested, diversity suffers.

\section{Newsgathering Routines}

When journalists discuss resources and diverse staffing, their observations are generally in the context of the effects on newsgathering. The benefits associated with boosting resources and staff diversity stem from their impact on the way news and current affairs content is generated. The perception is that traditional news values and the "daily grind" of producing stories are often impediments to more inclusive news, given the well-established rituals and norms of journalistic practice. In this study those 
elements of practice break down into four categories: (a) the agenda and hard news, (b) the assignment process, (c) the negative-news focus, and (d) sourcing norms.

\section{(a) The Agenda and Hard News} local, regional and national events that are expected to be important enough to generate news content for their programming needs. Agenda items are usually the "hard news" stories that focus on politics, government, policing and the courts. This is abundantly clear in the 58 pages of outlooks I collected while in the field. They are dominated by news conferences or media availabilities with easy access to sources and in that sense make newsgathering fast and efficient. The first story meeting of the day augments this list with original ideas. At a time of expanding demands and limited resources, many journalists argued, the priority becomes stories that "just have to be done". Even a veteran on the assignment desk saw avoiding this mindset as one of the biggest challenges, "to try to get off the agenda and get away from the same minute and a half ... the same thrust and the same voices and same faces". ${ }^{75}$ The difficulty in escaping the agenda was apparent in some of the assignment decisions in the story meeting. For example, there was a news conference related to the police shooting of a suspect, the facts of which were well established, but a reporter was still sent "just in case". Reporters were routinely dispatched to City Hall and other government sites as a matter of course, often to get reaction from politicians.

There is also a view that the need for inclusivity in news content is superseded by big breaking stories: "Sometimes we absolutely have to cover the car crash that's held up traffic for three hours or the floods or whatever shooting might have happened." 76 Some news staff suggested the agenda focus is driven by the need to compete with other stations, though this was never explicitly mentioned by assignment editors either in interviews or story meetings. Many felt, in the absence of resources (time and staffing), to properly ensure more inclusive content, newsgathering defaults to the agenda, and "then you're going to go to the most obvious, straightforward, predictable daily-chase route and you're going to watch all the other stations and see what they're doing". ${ }^{.7}$ Another journalist described how the constant demands for content and the primacy of the news agenda take a toll over time, and discourages more diverse reporting:

You don't want to miss the stories that everybody's covering, so you feel like, okay, we've got to plug this hole, this hole, this hole ... oh, well, we've only got five reporters and they're now all assigned to agenda stories, so why is anybody going to pitch a story that's original or pertains to a community that maybe the rest of the audience might not be as interested in? ${ }^{78}$

The agenda tends to be dominated by "hard news" over "soft news". One interviewee explained that hard news is perceived as "the real news ... that's your murders and corruption", and many reporters "feel that if they're not doing hard news, they're not credible journalists". ${ }^{79}$ Soft news tends to be lighter in nature, "featurey", less timely. Several participants noted the perception that "diverse" stories are regarded as soft news. Interviewees described many of the stories involving minority groups as "lowhanging fruit" focusing on celebrations of exotic culture. The hard versus soft news perception extends into another theme: the assignment process. 


\section{(b) Assignment Process}

41 According to the journalist referenced just above, the professional prejudice against soft news is prevalent among editors and producers responsible for assignment "and they equate any pitch that has to do with diverse communities as soft news and they say we don't have the resources; we don't have the space; we don't have the time; we can't count on that". ${ }^{80}$ Sending a reporter to court is certain to result in a story; sending someone to a First Nation where residents are raising cattle for the local food bank might not work out. Several interviewees pointed out young reporters arriving in the newsroom begin to see the professional prejudice at play and start to shape the stories they pitch to reflect that point of view, possibly to the exclusion of ideas related to minority communities.

\section{(c) The Negative-News Focus}

42 During the study, the newsroom's handling of one story drove a couple of angry staff members to my temporary office. Aboriginal Christians from across Canada have been gathering every summer for over a century in a rural community within the station's broadcast area to celebrate their faith. Thousands of people take in the event, steeped in ritual and spirituality. Despite the pageantry, mainstream media in the region rarely cover the festivities. However, when the provincial government released a health warning related to the water supply at the site of the celebration and organizers and participants continued with their rituals, the story appeared on the front page of a local newspaper. The early morning newsroom staff dispatched reporters to file quick stories. When news crews arrived on the scene, organizers initially reacted angrily and refused to be interviewed. Back in my office, a producer pointed out the missed opportunity to do a positive story, until it turned negative:

It's not negative against Aboriginal people, but it's a negative story, so they're all over it. Instead of doing, " 40,000 people going to [name withheld] that generations have gone to" ... Once a year we do a positive series on Aboriginal people, that's it, we're done. Why aren't we talking to them about ordinary things? ${ }^{81}$

Over the course of this study there were stories both positive and neutral related to the Aboriginal community that went to air, some of which have already been mentioned; however, the only other incident involving Aboriginal people that drew heavy media attention was a case of a homophobic attack on a gay student of First Nations ancestry. While the story was an opportunity for a marginalized voice to be heard, as one journalist observed, it still fell into the familiar trope of Aboriginal as victim.

As noted above, a number of reporters felt that the negative nature of news stories about minority ethno-cultural groups often creates a sense of mistrust. When a reporter calls, there is a presumption the coverage will cast a particular community in a bad light, as this journalist explained:

A story that usually involves conflict, to the extent that that's a racialized conflict or involves some ethnic element that's not a hundred per cent positive, communities start to go like "you're only interested in us when we're fodder for news". ${ }^{82}$

45 Another journalist observed that "every time they see a camera or a reporter it's going to be a bad news story and they're going to look stupid and therefore they don't want anything to do with it". ${ }^{83}$ With respect to Aboriginal communities, several members of 
staff described being confronted on reserves, even in cases where they were doing positive stories.

\section{(d) Sourcing Norms}

In the story meetings I attended, there was no mention of inclusivity or diversity in discussions of story merits, and very little examination of who the sources would (or should) be. When reporters were given their assignments - particularly in cases of ongoing coverage - it was fairly common to hear one reporter ask another for help ("Who's your guy on ...?"). In the case of a story relating to drugstore robberies, a journalist acknowledged having some trouble getting the piece to air because "our regular pharmacy" had gone out of business. Journalists all over the world maintain organized lists of contacts to save time in the news production process. In fact, most newsrooms maintain databases of sources; CBC's is known as "the rep file". At different times in the past this newsroom made attempts to diversify its lists of contacts, but as one journalist conceded, the rep file remains "a whole bunch of white people". ${ }^{84} \mathrm{~A}$ number of interviewees placed the established contacts routine in the context of increasingly limited resources, where the workload of multiple stories, coupled with deadline pressure, forces quick and easy choices of sources.

While journalists all seemed to understand their responsibility in developing contacts and relationships in different ethno-cultural communities, some expressed frustration in the apparent lack of media relations skills within those groups. They gave examples of stories or events they learned about well after the fact, and wished they had received advance notice - a news release, a phone call - so that they could have provided timely coverage. One journalist, citing the common theme of mistrust of the media among minority sources, found it difficult to explain the need for people to speak out in the interests of their communities to counter stereotypes and provide greater context and balance: "To me [trust] is the biggest thing, to actually get people to know that if they talk to you it's better than if they don't." 85

A number of reporters and producers acknowledged an overreliance on official sources such as politicians and police, yet the stories associated with these voices topped the agendas and rarely went unassigned in story meetings. One interviewee observed that, for a time, editorial staff used a strategy to limit clips of the "bureaucratic official or politician, who is invariably white and male", and go to the larger community for reaction. ${ }^{86}$ This journalist felt the newsroom has generally strayed from that format; however, there was a clear example of that strategy in television news coverage of a particularly dangerous highway in the region. The provincial government had announced plans for more rigorous enforcement, but the bulk of reaction came from a long-haul truck driver in a turban. A similar approach had been adopted with regard to "streeters", those vox populi items that attempt to provide a cross-section of public opinion. This practice, too, seemed to have been deployed somewhat sporadically. In one evening newscast there was a streeter clearly featuring minority and Aboriginal speakers, and another where all of the people were white. 


\section{Discussion} traditional, mainstream newsgathering routines and values established in the modernist era of the last century. These norms privilege dominant segments of society over the marginalized. A reliance on agenda-driven news, familiar sources, and voices of authority (police, politicians, experts, business leaders) crowds out minority perspectives. In this newsroom there is recognition of the impact these newsgathering norms have on content and strategies have been developed to mitigate the effects with hiring, awareness, community outreach and limiting the use of official sources. However, as was seen on a number of occasions over the course of this study, newsgathering norms are so steeped in mainstream bias that editorial staff often revert to familiar production patterns, circumventing efforts to improve diversity.

50 Numerous studies have previously detailed the way traditional newsgathering norms are a product of hegemony and tend to result in a news discourse dominated by elites, to the exclusion of marginalized voices. ${ }^{87}$ Longstanding and seminal ethnographies have documented the reliance on official, authoritative sources in the reporter's routine..$^{88}$ More recent scholarship points out that this dependency "leads to the exclusion and marginalization of minority voices". ${ }^{89}$ At the same time established fields of news sources - politics, business and academia - "are dominated by White men". ${ }^{90}$ The journalists in this study also noted the prevailing "whiteness" of sources and contacts. Yet this research also finds that the reliance on familiar, proven contacts, "your guy on ...", can be circumvented by awareness and recognition of its narrowing effect on news content, by simply having a strategy to deal with it. For a time, reporters in this newsroom limited their use of official sources and focused their coverage on community reaction as a way to better reflect the city. A similar strategy of inclusivity was deployed for streeters; however, interviewees believed such approaches had become more sporadic - the consequence, some felt, of limited resources.

51 Interview and participant observation data provided examples of how minority journalists bring diversity to the news content. However, there is also concern that the objectivity ideal is unevenly applied, that their "judgment is always in question" in stories related to their ethnicity, though white reporters do not face similar professional scrutiny in covering mainstream issues. Nonetheless, minority journalists generally believe "it's OK to be the go-to-person" for their specific ethno-cultural communities. This is consistent with the findings of a study of the BBC, which describes how minority journalists at the BBC can experience the "burden of representation", but suggests that burden can be mitigated when they recognize "the need to counter dominant images" about their community. ${ }^{91}$ In scholarship related to diasporic and indigenous media, some scholars have highlighted the need for "self-representation" in the news discourse to counter under- and misrepresentation, allowing minority journalists to reveal their own culture and "historical realities to themselves and the broader societies that have stereotyped or denied them". ${ }^{92}$ It is that challenge to stereotypic, mainstream perceptions of ethno-cultural minorities that a diverse newsroom can bring to the mainstream news discourse.

However, this study and others also highlight the importance of diversity throughout he organization, including management and assignment personnel..$^{93}$ In 1968 , the Kerner Commission in the United States already called for news organizations to hire not just 
black journalists, but black editors too. ${ }^{94}$ Heider, in his ethnography of three US newsrooms in ethnically diverse markets, relates the background of news directors to the "naturalized" decision-making process:

Why is it that each night only certain events somehow rise to the top of the news agenda? Is it because they are the most important and pertinent to the community, or is it because news workers, due to homogeneity of backgrounds and socialization of news norms, repeatedly select the same story? ${ }^{95}$

This helps explains some of the editorial decisions noted in this analysis, where a story about Aboriginal people is ignored until it is more widely discussed by the mainstream (often in a negative context), stories related to education are assigned and produced even when children are enjoying summer vacation; and stories about Ramadan may or may not get to air. Established newsgathering routines are steeped in Eurocentric assumptions of what news is, which can be challenged by non-white perspectives, if there are diverse members of the news staff willing to "push" an alternative point of view.

In both Heider's study and this analysis there is recognition that assigning practices can provide another impediment to inclusivity. Several journalists - some from a diverse background - pointed out that new reporters learn what kind of stories to pitch based on what they observe at story meetings - see Heider's "socialization of news norms", quoted above. The suggestion is that stories from minority communities are perceived as soft news and often go unassigned. Eventually those reporters target their pitch in a way that is deemed to meet the news values of the assignment desk, concentrating on hard, mainstream news. The concern this raises is that new minority reporters might refrain from tapping into their own communities to get stories, or from challenging dominant perspectives advocated by senior producers. One US scholar describes this scenario as "the illusion of inclusion". ${ }^{96}$ Other US studies have noted this effect but generally found that diverse newsrooms provide more inclusive, equitable coverage..$^{97}$ The experience seems to be sporadic, as was observed in this study, and varies from newsroom to newsroom. Nishikawa et al. attempt to explain why:

We show that some minority journalists feel they bring a different perspective to the newsroom. Perhaps a critical mass of minority journalists who share this perspective must be in place to make real changes in news outputs. A lone voice, asking the pointed question, waving the red flag, might well be drowned out by a chorus of often more senior and influential White voices. Thus, whether minority journalists have a positive impact on news coverage may depend on how many journalists are present who share that goal. ${ }^{98}$

The $\mathrm{CBC}$ newsroom at the center of this study does include a number of journalists from minority backgrounds, but is there that "critical mass" to bring "real changes" to the news content? What might that critical mass look like? Those are important questions that cannot be answered here, but point the way to future research.

\section{Conclusion}

This study demonstrates the significant challenges media organizations face in trying to provide better coverage of Aboriginal peoples and minority groups in Canada. The approaches adopted by industry and government - awareness and training, equitable hiring and legislated mandates to "reflect" Canadian society - are too vague and 
simplistic to result in real change, without explicit recognition that traditional news production rituals privilege a mainstream bias, and thwart diversity efforts. Despite a high degree of awareness of, and a management commitment to, diversity at this CBC station, there was widespread agreement among staff that its news coverage still needs to improve; that white sources are over-represented, that minorities and Aboriginal peoples are too often fodder for only negative news, and that "good" stories about those communities "fall through the cracks".

Principal among the findings in this research is the influence of assignment personnel who tend to come from a white, mainstream background, and who may inadvertently frame coverage from that dominant perspective. There were suggestions - even among assignment editors - that greater diversity in the organization's higher ranks might result in more reflective content. Of course this remains to be seen, given low minority participation rates among news directors in Canada, ${ }^{99}$ and the door is open to future research examining the impact of minority editors on content. It is conceivable that they too feel the normative pressures of mainstream newsgathering.

It is worth noting that many of the diversity measures displayed in this $\mathrm{CBC}$ newsroom, if fully and consistently deployed, might well go a long way to improving media content. However, as a number of interviewees observed, the approach seems to be "haphazard" and "sporadic". Fleras suggests "the challenge is formidable ... the metaphorical equivalent of walking up a down-escalator whose speed is controlled by seemingly invisible hands". ${ }^{100}$ In an era of convergence, when traditional news media are struggling to maintain audiences, broadcasters can ill afford to drive away consumers with coverage that either does not reflect them or reflects them in consistently negative ways.

\section{BIBLIOGRAPHY}

Alia, Valerie. "Scattered Voices, Global Vision: Indigenous Peoples and the New Media Nation." In The Media of Diaspora, edited by Karim H. Karim, 36-50. New York: Routledge, 2003.

American Society of News Editors. “ASNE Diversity History.” Accessed October 7, 2010. http:// asne.org/key_initiatives/diversity.aspx.

Anderson, Mark Cronlund, and Carmen L. Robertson. Seeing Red: A History of Natives in Canadian Newspapers. Winnipeg, Canada: University of Manitoba Press, 2011.

Barber, Marsha, and Ann Rauhala. "The Canadian News Directors Study: Demographics and Political Leanings of Television Decision-Makers." Canadian Journal of Communication 30(2) (2005): 281-292.

Byerly, Carolyn M., and Clint C. Wilson II. “Journalism as Kerner Turns 40: Its Multiculticultural Problems and Possibilities." The Howard Journal of Communications 20 (2009): 209-221.

Canadian Association of Broadcasters. "Reflecting Canadians: Best Practices for Cultural Diversity in Private Television. A Report by the Task Force for Cultural Diversity on Television." Accessed 
September 9, 2010. http://www.cab-acr.ca/english/social/diversity/taskforce/report/ cdtf_report_jul04.pdf.

Canadian Broadcasting Corporation. "Inclusion and Diversity: Engaging to Break Boundaries." Accessed April 27, 2013. http://www.cbc.radio-canada.ca/_files/cbcrc/documents/equity/ 2012-15-inclusion-diversity-plan.pdf.

-. “About Hockey Night in Punjabi.” Last modified July 9, 2013. http://www.cbc.ca/sports/ hockeynightincanada/punjabi/video/\#id=2393594950.

Canadian Human Rights Commission. "Frequently Asked Questions About Employment Equity." Last modified August 27, 2009. http://www.chrc-ccdp.ca/publications/ee_faq_ee-en.asp.

Charmaz, Kathy. Constructing Grounded Theory. London: Sage, 2006.

Chow-White, Peter, and Rob McMahon. "Examining the 'Dark Past' and 'Hopeful Future' in Representations of Race and Canada's Truth and Reconciliation Commission." In Expanding Peace Journalism: Comparative and Critical Approaches, edited by Ibrahim Saga Shaw, Jake Lynch and Robert A. Hackett, 345-373. Sydney: Sydney University Press, 2011.

Clark, Brad. "Reflecting Which Canada? A Source Analysis of Canadian Network Television News." International Journal of Diverse Identities 12(1) (2013): 33-45.

Corbin, Juliet, and Nicholas L. Holt. "Grounded Theory." In Research Methods in The Social Sciences, edited by Bridget Somekh and Cathy Lewin, 49-55. London: Sage, 2005.

Cottle, Simon. "A Rock and a Hard Place: Making Ethnic Minority Television.” In Ethnic Minorities and the Media, edited by Simon Cottle, 100-117. Buckingham: Open University Press, 2000.

-. "Media Research and Ethnic Minorities: Mapping the Field." In Ethnic Minorities and the Media, edited by Simon Cottle, 1-30. Buckingham: Open University Press, 2000.

-. "Ethnography and News Production: New(s) Developments in the Field." Sociology Compass 1(1) (2007): 1-16.

Downing, John, and Charles Husband. Representing "Race": Racisms, Ethnicities and Media. London: Sage, 2005.

Entman, Robert, and Andrew Rojecki. The Black Image in the White Mind: Media and Race in America. Chicago: University of Chicago Press, 2001.

Ericson, Richard V., Patricia M. Baranek, and Janet B. L. Chan. Negotiating Control: A Study of News Sources. Toronto: University of Toronto Press, 1989.

Fishman, Mark. Manufacturing the News. Austin: University of Texas Press, 1980.

Fleras, Augie. The Media Gaze: Representations of Diversities in Canada. Vancouver: UBC Press, 2011.

Fleras, Augie, and Jean Lock Kunz. Media and Minorities: Representing Diversity in Multicultural Canada. Toronto: Thompson Educational Publishing, 2001.

Gans, Herbert. Deciding What's News: A Study of CBS Evening News, NBC Nightly News, Newsweek and Time. New York: Random House, 1979.

Ginsburg, Faye. "Embedded Aesthetics: Creating a Discursive Space for Indigenous Media." Cultural Anthropology 9(3) (1994): 365-382.

Goldbart, Juliet, and David Hustler. "Ethnography." In Research Methods in the Social Sciences, edited by Bridget Somekh and Cathy Lewin, 16-23. London: Sage, 2005. 
Government of Canada. "Broadcasting Act, c. 1991 s. 3(1)." Justice Laws Website. Last modified October 11, 2013. http://laws.justice.gc.ca/eng/B-9.01/page-1.html\#anchorbo-ga:1_I-gb:s_3;. Hall, Stuart. "Encoding/decoding." In Culture, Media, Language, edited by Stuart Hall, Dorothy Hobson, Andrew Love and Paul Willis, 128-138. London: Hutchinson, 1980.

Harding, Robert. "Historical Representations of Aboriginal People in the Canadian News Media." Discourse \& Society 17(205) (2006).

-. "The Demonization of Aboriginal Child Welfare Authorities in the News." Canadian Journal of Communication 35(1) (2010): 85-108.

Heider, Don. White News: Why Local News Programs Don't Cover People of Colour. Mahwah, NJ: Lawrence Erlbaum Associates, 2000.

Henry, Frances, and Carol Tator. Discourses of Domination: Racial Bias in the Canadian EnglishLanguage Press. Toronto: University of Toronto Press, 2002.

Hier, Sean P. "Representing Race: Are Canadian News Media Racist? Racism, Media and Analytical Balance." In Communication in Question: Competing Perspectives on Controversial Issues in Communication Studies, edited by Josh Greenberg and Charlene D. Elliot, 131--137. Toronto, Canada: Thompson-Nelson, 2008.

Hier, Sean P., and Josh L. Greenberg. "Constructing a Discursive Crisis: Risk, Problematization and Illegal Chinese in Canada." Ethnic and Racial Studies 25(3) (2002): 490-513.

Hulten, Gunilla. "Diversity Disorders: Ethnicity and Newsroom Cultures." Conflict \& Communication Online 8(2) (2009): 1-14.

Jiwani, Yasmin. Discourses of Denial: Mediations of Race, Gender and Violence. Vancouver: UBC Press, 2006.

Karim, Karim H. "The Historical Resilience of Primary Stereotypes: Core Images of the Muslim Other." In The Language and Politics of Exclusion: Others in Discourse, edited by Stephen H. Riggins, 197-218. Thousand Oaks: Sage, 1997.

Kerner Commission. 1968 Report of the National Advisory Commission on Civil Disorders. New York: Pantheon Books, 1988.

Kretzschmar, Sonja. "Diverse Journalists in a Diverse Europe? Impulses for a Discussion on Media and Integration.” European Studies 24 (2007): 203-226.

Leedy, Paul D., and Jeanne Ellis Ormrod. Practical Research: Planning and Design. 9th. ed. Upper Saddle River, NJ: Pearson, 2010.

Machin, David. Ethnographic Research for Media Studies. London: Arnold Publishers, 2002.

Mahtani, Minelle. "Representing Minorities: Canadian Media and Minority Identities." Canadian Ethnic Studies 33(3) (2001): 99-133.

-. "Critiquing the Critiques about Media and Minority Research in Canada." Canadian Journal of Communication 34(4) (2009): 715-719.

Mahtani, Minelle, Frances Henry, and Carol Tator. "Discourse, Ideology, and Constructions of Racial Inequality." In Communication in Question: Competing Perspectives on Controversial Issues in Communication Studies, edited by Josh Greenberg and Charlene D. Elliot, 120-130. Toronto: Thompson-Nelson, 2008.

Miller, John. Yesterday's News: Why Canada's Daily Newspapers are Failing us. Halifax: Fernwood, 1998. 
-. “Who's Telling the News? Racial Representation Among News Gatherers in Canada's Daily Newsrooms." International Journal of Diversity in Organizations, Communities and Nations 5 (2005): 110.

Murray, Catherine A. "Designing Monitoring to Promote Cultural Diversification in TV." Canadian Journal of Communication 34(4) (2009): 675-699.

Nishikawa, Katsuo, Terri L. Towner, Rosalee Clawson, and Eric Waltenburg. "Interviewing the Interviewers: Journalistic Norms and Racial Diversity in the Newsroom." The Howard Journal of Communications 20 (2009): 242-259.

Papper, Robert. "The Face of the Workforce." Radio-Television Digital News Association. Accessed October 9, 2010. http://www.rtnda.org/pages/media_items/the-face-of-the-workforce1472.php.

Pease, Edward C., Erna Smith, and Federico Subervi. The News and Race Models of Excellence Project Overview: Connecting Newsroom Attitudes Toward Ethnicity and News Content. St. Petersburg, FL: Poynter Institute for Media Studies, 2001.

Perigoe, Ross, and Barry Lazar. "Visible Minorities and Native Canadians in National Television News Programs.” In Critical Studies of Canadian Mass Media, edited by Marc Grenier, 259-272. Toronto: Buttersworth, 1992.

Pierro, Robin, Jorge Barrera, Cindy Blackstock, Robert Harding, Duncan McCue, and Mike Metatawabin. Buried Voices: Media Coverage of Aboriginal Issues in Ontario. Toronto: Journalists for Human Rights, 2013.

RTNDA Canada. Everyone's Story: Reflecting Canada's Diversity. Toronto, Canada: Radio-Television News Directors Association, 2006.

Shoemaker, Pamela, and Stephen Reese. Mediating the Message: Theories of Influence on Mass Media Content. 2nd. ed. White Plains, NY: Longman, 1996.

Spears, George, Kasia Seydegart, and Pat Zulinov. The News Balance Report: Interim Report. Toronto: Canadian Broadcasting Corporation, 2010.

Statistics Canada. 2006 Census: Ethnic Origin, Visible Minorities, Place of Work and Mode of Transportation. Last modified April 2, 2008. http://www.statcan.gc.ca/daily-quotidien/080402/ dq080402a-eng.htm.

Strauss, Anselm, and Juliet Corbin. Basics of Qualitative Research: Techniques and Procedures for Developing Grounded Theory. 2nd. ed. Thousand Oaks, CA: Sage, 1998.

Tuchman, Gaye. Making News: A Study in the Construction of Reality. New York, NY: Free Press, 1978.

Tunstall, Jeremy. The Westminster Lobby Correspondents: A Sociological Study of National Political Journalism. London: Routledge, 1970.

Van Dijk, Teun A. Racism and the Press. London: Routledge, 1991.

White, David Manning. “The 'Gate Keeper': A Case Study in the Selection of News.” In Social Meanings of News: A Text-Reader, edited by by Daniel Allen Berkowitz, 63-71. Thousand Oaks, CA: Sage, 1997[1950].

Wilson II, Clint C. Black Journalists in Paradox: Historical Perspectives and Current Dilemmas. New York: Greenwood Publishing Group, 1991.

-. "The Paradox of Africa American Journalists." In Ethnic Minorities and the Media, edited by Simon Cottle, 85-99. Buckingham: Open University Press, 2000. 
Zeldes, Geri, and Frederick Fico. "Race and Gender: An Analysis of Sources and Reporters in the Networks' Coverage of the 2000 Presidential Campaign." Mass Communication \& Society 8(4) (2005): 373-385.

Zeldes, Geri, Frederick Fico, and Arvind Diddi. "Race and Gender: An Analysis of the Sources and Reporters in Local Television Coverage of the 2002 Michigan Gubernatorial Campaign." Mass Communication \& Society 10(3) (2007): 345-363.

\section{ENDNOTES}

1. Augie Fleras and Jean Lock Kunz, Media and Minorities: Representing Diversity in Multicultural Canada (Toronto: Thompson Educational Publishing, 2001); Minelle Mahtani, "Representing Minorities: Canadian Media and Minority Identities," Canadian Ethnic Studies 33(3) (2001); Sean P. Hier and Josh L. Greenberg, "Constructing a Discursive Crisis: Risk, Problematization and Illegal Chinese in Canada," Ethnic and Racial Studies 25(3) (2002); Frances Henry and Carol Tator, Discourses of Domination: Racial Bias in the Canadian English-Language Press (Toronto: University of Toronto Press, 2002); Robert Harding, "Historical Representations of Aboriginal People in the Canadian News Media," Discourse \& Society 17(205) (2006); Mark Cronlund Anderson and Carmen L. Robertson, Seeing Red: A History of Natives in Canadian Newspapers (Winnipeg: University of Manitoba Press, 2011).

2. "Broadcasting Act, c. 1991 s. 3(1)," Government of Canada, accessed August 13, 2010, http:// laws.justice.gc.ca/eng/B-9.01/page-1.html\#anchorbo-ga:I_I-gb:s_3;.

3. Mahtani, "Representing Minorities," 104.

4. See Canadian Association of Broadcasters, "Reflecting Canadians: Best Practices for Cultural Diversity in Private Television. A Report by the Task Force for Cultural Diversity on Television," accessed September 9, 2010, http://www.cab-acr.ca/english/social/diversity/taskforce/report/ cdtf_report_jul04.pdf; RTNDA Canada, Everyone's Story: Reflecting Canada's Diversity, (Toronto: Radio-Television News Directors Association, 2006).

5. Canadian Human Rights Commission, "Frequently Asked Questions About Employment Equity," Canadian Human Rights Commission, last modified August 27, 2009, http://www.chrcccdp.ca/publications/ee_faq_ee-en.asp.

6. Perigoe and Lazar, "Visible minorities and Native Canadians in National Television News Programs," in Critical Studies of Canadian Mass Media, ed. Marc Grenier (Toronto: Butterworths, 1992); George Spears, Kasia Seydegart, and Pat Zulinov, The News Balance Report: Interim Report (Toronto: Canadian Broadcasting Corporation, 2010); Brad Clark, "Reflecting Which Canada? A Source Analysis of Canadian Network Television News," International Journal of Diverse Identities 12(1) (2013).

7. Minelle Mahtani, Frances Henry and Carol Tator, "Discourse, Ideology, and Constructions of Racial Inequality," in Communication in Question: Competing Perspectives on Controversial Issues in Communication Studies, eds. Josh Greenberg and Charlene D. Elliot (Toronto: Thompson Nelson, 2008), 127.

8. Mahtani, "Representing Minorities," 105.

9. Robert, Harding, "The Demonization of Aboriginal Child Welfare Authorities in the News," Canadian Journal of Communication 35(1) (2010), 101.

10. Simon Cottle, "Media Research and Ethnic Minorities: Mapping the Field," in Ethnic Minorities and the Media, ed. Simon Cottle (Buckingham: Open University Press, 2000), 16.

11. Sean P. Hier, "Representing Race: Are Canadian News Media Racist? Racism, Media and Analytical Balance," in Communication in Question: Competing Perspectives on Controversial Issues in 
Communication Studies, eds. Josh Greenberg and Charlene D. Elliot (Toronto: Thompson Nelson, 2008), 132.

12. Simon Cottle, "Ethnography and News Production: New(s) Developments in the Field," Sociology Compass 1(1) (2007), 12.

13. Augie Fleras, The Media Gaze: Representations of Diversities in Canada (Vancouver: UBC Press, 2011), 263.

14. Teun A.van Dijk, Racism and the Press (London: Routledge, 1991), 21.

15. Sonja Kretzschmar, "Diverse Journalists in a Diverse Europe? Impulses for a Discussion on Media and Integration," European Studies 24 (2007), 220.

16. Fleras, The Media Gaze, 56.

17. Yasmin Jiwani, Discourses of Denial: Mediations of Race, Gender and Violence (Vancouver: UBC Press, 2006), 42.

18. Henry and Tator, Discourses of Domination, 23.

19. See Karim H. Karim, "The Historical Resilience of Primary Stereotypes: Core Images of the Muslim Other," in The Language and Politics of Exclusion: Others in Discourse, ed. Stephen Harold Riggins, (Thousand Oaks: Sage, 1997); Sean P. Hier and Josh L. Greenberg, "Constructing a Discursive Crisis: Risk, Problematization and Illegal Chinese in Canada," Ethnic and Racial Studies 25(3) (2002).

20. Anderson and Robertson, Seeing Red, 7.

21. Fleras and Kunz, Media and Minorities, 146.

22. Robin Pierro, Jorge Barrero, Cindy Blackstock, Robert Harding, Duncan McCue, and Mike Metawawin, Buried Voices: Media Coverage of Aboriginal Issues in Ontario, (Toronto: Journalists for Human Rights, 2013), 17. Retrieved from http://www.jhr.ca/en/aboutjhr/downloads/ publications/buried_voices.pdf; Peter Chow-White and Robert McMahon, "Examining the 'Dark Past' and 'Hopeful Future' in Representations of Race and Canada's Truth and Reconcilliation Commission," in Expanding Peace Journalism: Comparative and Critical approaches, eds. Ibrahim Seaga Shaw, Robert A. Hackett, (Sydney: Sydney University Press. 2011), 360.

23. Carolyn M. Byerly, and Clint C. Wilson II, "Journalism as Kerner Turns 40: Its Multiculticultural Problems and Possibilities," The Howard Journal of Communications 20 (2009), 211.

24. Kerner Report, (New York: Pantheon Books), 383-385; ibid., 212.

25. See RTNDA Canada, Everyone's Story; Robert Papper, "The Face of the Workforce," accessed October 9, 2010, http://www.rtnda.org/pages/media_items/the-face-of-the-workforce1472.php; American Society of News Editors, "ASNE Diversity History, accessed October 7, 2010, http:// asne.org/key_initiatives/diversity.aspx.

26. See Don Heider, White News: Why Local News Programs Don't Cover People of Colour (Mahwah, NJ: Lawrence Erlbaum Associates, 2000); Fleras and Kunz, Media and Minorities; Edward C. Pease, Erna Smith, and Federico Subervi, The News and Race Models of Excellence Project Overview: Connecting Newsroom Attitudes Toward Ethnicity and News Content (St. Petersburg, FL: Poynter Institute for Media Studies, 2001); Henry and Tator, Discourses of Domination; John Miller, "Who's Telling the News? Racial Representation Among News Gatherers in Canada's Daily Newsrooms," International Journal of Diversity in Organizations, Communities and Nations 5 (2005).

27. Canadian Association of Broadcasters, Reflecting Canadians, 42.

28. RTNDA Canada, "Everyone's Story," 36.

29. Catherine A. Murray, "Designing Monitoring to Promote Cultural Diversification in TV," Canadian Journal of Communication 34(4), (2009), 689.

30. John Miller, “Who's Telling the News?", 3.

31. Stuart Hall, "Encoding/decoding," in Culture, Media, Language, eds. Stuart Hall, Dorothy Hobson, Andrew Love and Paul Willis (London: Hutchinson, 1980), 131.

32. Ibid., 138. 
33. Pamela Shoemaker and Stephen Reese, Mediating the Message: Theories of Influence on Mass Media Content 2nd ed. (White Plains: Longman, 1996), 235.

34. Mark Fishman, Manufacturing the News (Austin: University of Texas Press, 1980), 63.

35. Ibid., 56.

36. Richard V. Ericson, Patricia M. Baranek and Janet B.L. Chan, Negotiating Control: A Study of News Sources (Toronto: University of Toronto Press, 1989), 3.

37. Robert Entman and Andrew Rojecki, The Black Image in the White Mind: Media and Race in America (Chicago: The University of Chicago Press, 2001), 73.

38. Katsuo Nishikawa et al., "Interviewing the Interviewers: Journalistic Norms and Racial Diversity in the Newsroom," The Howard Journal of Communications 20 (2009), 254.

39. Pease, Smith and Subervi, The News and Race Models of Excellence Project Overview, 41.

40. Clint C. Wilson II, "The Paradox of Africa American Journalists," in Ethnic Minorities and the Media, ed. Simon Cottle (Buckingham: Open University Press, 2000), 97.

41. Simon Cottle, "A Rock and a Hard Place: Making Ethnic Minority Television," in Ethnic Minorities and the Media, ed. Simon Cottle (Buckingham: Open University Press, 2000), 106.

42. Minelle Mahtani, "Critiquing the Critiques About Media and Minority Research in Canada," Canadian Journal of Communication 34(4) (2009), 718.

43. John Downing and Charles Husband, Representing "Race": Racisms, Ethnicities and Media (London: Sage, 2005), 50.

44. David Manning White, "The 'Gate Keeper': A Case Study in the Selection of News," in Social Meanings of News: A Text-Reader, ed. Daniel Allen Berkowitz (1950, Thousand Oaks, CA: Sage, 1997), 63.

45. See Gaye Tuchman, Making News: A Study in the Construction of Reality (New York: Free Press, 1978); Jeremy Tunstall, The Westminster Lobby Correspondents: A Sociological Study of National Political Journalism (London: Routledge, 1970); Herbert Gans, Deciding What's News: A Study of CBS Evening News, NBC Nightly News, Newsweek and Time (New York: Random House, 1979); Fishman, Manufacturing the News.

46. Cottle, "Media Research and Ethnic Minorities," 16.

47. David Machin, Ethnographic Research for Media Studies (London: Arnold Publishers, 2002), 86.

48. Juliet Goldbart and David Hustler "Ethnography," in Research Methods in the Social Sciences, eds. Bridget Somekh and Cathy Lewin (London: Sage, 2005), 17.

49. Paul D. Leedy, and Jeanne Ellis Ormrod, Practical Research: Planning and Design, 9th ed. (Upper Saddle River, NJ: Pearson, 2010), 144.

50. Juliet Corbin and Nicholas L. Holt, "Grounded Theory," in Research Methods in the Social Sciences, eds. Bridget Somekh and Cathy Lewin (London: Sage, 2005), 49.

51. Kathy Charmaz, Constructing Grounded Theory (London: Sage, 2006), 130.

52. Ibid., 22.

53. "Broadcasting Act, c. 1991 s. 3(1)," Government of Canada.

54. Canadian Broadcasting Corporation, “About Hockey Night in Punjabi," last modified July 9, 2013, http://www.cbc.ca/sports/hockeynightincanada/punjabi/video/\#id=2393594950.

55. For example, $12 \%$ of network television reporters at $\mathrm{CBC}$ come from visible minorities (as defined by the Employment Equity Act) compared to $8 \%$ at the private networks. At $\mathrm{CBC}$ visible minority and Aboriginal news sources make up a combined $17 \%$ of the total, compared to $11 \%$ in private broadcaster stories. See Spears, Seydegart and Zulinov, The News Balance Report, 37-38.

56. Canadian Broadcasting Corporation, Inclusion and Diversity: Engaging to Break Boundaries, retrieved April 27, 2013 from CBCRadio/Canada, http://www.cbc.radio-canada.ca/_files/cbcrc/ documents/equity/2012-15-inclusion-diversity-plan.pdf, 7.

57. Corbin and Holt, "Grounded Theory," 51.

58. Anselm Strauss and Juliet Corbin, Basics of Qualitative Research: Techniques and Procedures for Developing Grounded Theory, 2nd ed. ( Thousand Oaks, CA: Sage, 1998), 57. 
59. Charmaz, Constructing Grounded Theory, 57.

60. Interview 17, CBC manager, July 27, 2012.

61. Interview 5, CBC journalist, July 18, 2012.

62. This analysis was not available to the researcher.

63. Interview $12, \mathrm{CBC}$ manager, July $26,2012$.

64. This data was not available to the researcher.

65. Interview 6, CBC journalist, July 19, 2012.

66. Interview 2, CBC journalist, July 17, 2012.

67. Interview 10, CBC journalist, July 25, 2012.

68. Interview 6.

69. Interview 7, CBC journalist, July 20, 2012.

70. Interview 11, CBC journalist, July 25, 2012.

71. Interview $4, C B C$ journalist, July 18, 2012.

72. Interview 11.

73. Interview 3, CBC journalist, July 17, 2012.

74. Interview $1, C B C$ journalist, July 16, 2012.

75. Interview 9, CBC manager, July 24, 2012.

76. Interview 14, July 27, 2012.

77. Interview 7.

78. Interview 2.

79. Interview 3.

80. Ibid.

81. Interview 11.

82. Interview 7.

83. Interview 14.

84. Interview 1.

85. Interview 14.

86. Interview 6.

87. See Hall, "Encoding/Decoding"; Shoemaker and Reese, Mediating the Message; Entman and Rojecki, The Black Image in the White Mind.

88. See Leon Sigal, Reporters and Officials (Lexington: D.C. Heath, 1973); Fishman, Manufacturing the News; Ericson, Baranek and Chan, Negotiating Control.

89. Nishikawa et al., "Interviewing the Interviewers," 244.

90. Geri Zeldes and Frederick Fico, "Race and Gender: An Analysis of Sources and Reporters in the Networks' Coverage of the 2000 Presidential Campaign," Mass Communication \& Society 8(4) (2005), 382.

91. Cottle, “A Rock and a Hard Place," 112.

92. Faye Ginsburg, "Embedded Aesthetics: Creating a Discursive Space for Indigenous Media," Cultural Anthropology 9(3), 378; see also Valerie Alia, "Scattered Voices, Global Vision: Indigenous Peoples and the New Media Nation," in The Media of Diaspora, ed. Karim H. Karim (New York: Routledge, 2003), 37.

93. See Heider, White News; Wilson II, "The Paradox of Africa American Journalists"; Pease, Smith and Subervi, The News and Race Models of Excellence Project Overview; Gunilla Hulten, "Diversity Disorders: Ethnicity and Newsroom Cultures," Conflict \& Communication Online 8(2) (2009).

94. Byerly and Wilson II, "Journalism as Kerner Turns 40," 212.

95. Heider, White News, 15.

96. Clint C. Wilson II, Black Journalists in Paradox: Historical Perspectives and Current Dilemmas (New York: Greenwood Publishing Group, 1991), 153.

97. See Pease, Smith and Subervi, The News and Race Models of Excellence Project; Nishikawa et al., "Interviewing the Interviewers". 
98. Nishikawa et al., "Interviewing the Interviewers," 255.

99. Marsha Barber and Ann Rauhala, "The Canadian News Directors Study: Demographics and Political Leanings of Television Decision-Makers," Canadian Journal of Communication 30(2) (2005), 288.

100. Fleras, The Media Gaze, 263.

\section{ABSTRACTS}

In Canada, as in other Western countries, non-white ethno-cultural groups are often portrayed in negative, stereotypic ways, or they are virtually invisible in the media discourse. This study examines the forces that shape news content at its principal site of production: the newsroom. A participant observer methodology was used to analyze a Canadian Broadcasting Corporation (CBC) news and current affairs operation, specifically the influence of production norms on the coverage of minority groups. The analysis reveals how corporate culture, hiring diverse staff and the deployment of more resources can all work to bring diversity to news content. However, in this newsroom, more inclusive journalism remains sporadic, as mainstream bias pervades newsgathering routines.

\section{INDEX}

Keywords: diversity, minorities, Aboriginal, inclusion, television news, mainstream media, Canadian television, ethnography, newsroom study, Canadian Broadcasting Corporation (CBC)

\section{AUTHOR}

\section{BRAD CLARK}

Brad Clark is an associate professor of broadcast journalism at Mount Royal University in Calgary, Alberta, Canada. Before entering the academy he worked as a journalist for 20 years, including six as a national radio reporter for the Canadian Broadcasting Corporation $(\mathrm{CBC})$. His research interests include media representations of minority groups, professional ideology and ethics. 